\title{
Care for the Environment and Environmental Crime Based on Theravada Buddhist Philosophy
}

\author{
Dittita Tititampruk ${ }^{*}$ and Tanet Ketsil ${ }^{\#}$
}

Faculty of Social Sciences and Humanities, Mahidol University

\begin{abstract}
From past to present, global compressions on human and environmental systems are more likely to increase than ever before in human history. With the science and technology advancement, we are living in the age of the global village that enables more convenient and brings us closer together. However, this also means that human being is suffering from global environmental crisis including the threat of war, economic crises, racial conflicts, environmental degradation, and environmental crime. This paper represents library-based work to date in Buddhist contemporary and useful perspectives and strategies on environmental protection and prevention in the backdrop of growing consumerism and capitalism influenced by western cultural in post-globalization era. Comparing to other countries, Thailand faces various environmental problems and some of them could become to environmental crime such as illegal wildlife trade; smuggling ozone-depleting substances; illicit trade in hazardous waste and pollution; illegal mining; illegal, unregulated and unreported fishing; illegal logging and associated trade in stolen timber. Since Thailand is one of largely Buddhist practical countries, measures to conserve the environment can draw on the principles and precepts of Lord Buddha's teachings, known as Tripitaka. In Lord Buddha's lifetime, environmental problems were not salient, but surprisingly, Lord Buddha recognised such problems because they are related to natural law. Accordingly, he established disciplinary rules for monks to live as models of not destroying the environment. The five precepts of Buddhism are the examples of the main principals in Buddhism which is regulations regarding the relation with environmental crime protection and humanity.
\end{abstract}

Keywords: Buddhist, Environmental crime, Environmental protection, Buddhist Five Precept, Contemporary society, Theravada Buddhist philosophy, Thailand.

\section{INTRODUCTION}

The world has undergone many changes because of human activities, including global environmental changes. Indeed, environmental changes are increasing, contributing to climate change, which, in turn, causes unbalances in the natural world. For instance, the exploitation of natural resources that are not replaceable, as seen in the case of fossil fuel burning, has led to the greenhouse effect (Choeikiwong 2012). Deforestation has increased because of ignorant actions by villagers and the indifference of both the government and larger society. Environmental change worldwide has led to effects such as unusual precipitation, flooding and heavy snowfall. It is even a cause of polar ice melting at the North Pole, which has contributed to the increasing level of Pacific Ocean water, a phenomenon associated with earthquakes (Chumsai Na Ayudhya and Dhammasakiyo, 2015).

Apart from the above-mentioned problems, Thailand and Chiangmai faced with the continuing severe air pollution during the beginning of 2019 . The government defined the emergency measures for solving the air pollution problems. Scholars and the group of

\footnotetext{
*Address correspondence to this author at the Department of Social Sciences, Faculty of Social Sciences and Humanities, Mahidol University, Salaya, Phutthamonthon, Nakhon Pathom 73170 Thailand; Tel: +6681-926-6287; E-mail: dittita.tit@mahidol.ac.th

"E-mail co-author: tanet.ket@mahidol.ac.th
}

independent entity sent the alarm about the air pollution problems at intervals from the reports of Greenpeace group (Green Peace, 2017). In Thailand, the ambient airborne particles were estimated. It found that in 2017, the 24-hour average which was examined was in the range of $2-116 \mu \mathrm{g} / \mathrm{m}^{3}$. The maximum average of all over the country was $74 \mu \mathrm{g} / \mathrm{m}^{3}$ (The standard value was at 50 ). The annual average was in the range of 9-36 $\mathrm{\mu g} / \mathrm{m}^{3}$ (The standard value was at 25 ). The standard value was about 40-50 days per year. During January-March, from checking the causes of ambient airborne particles basically, it found that the problem came from burning the agricultural materials and from cooking producing smoke. It was about 40 $45 \%$. $30-35 \%$ was from traffic and vehicles. $10-15 \%$ was from industry. Most of particles coming from construction and dust road are bigger than PM2.5. From the result measuring the faraway pollution from the remote sensing in many provinces like in the areas of central and northeastern regions, the quantity of ambient airborne particles PM2.5 which was examined was over the standard value during January-March. The annual average of ambient airborne particles quantity was over the standard value especially in Chiangmai. The 24-hour average quantity of ambient airborne particles was during 36-239 $\mathrm{\mu g} / \mathrm{m}^{3}$ (Theerapong, 2019).

Various countries including Thailand signed a United Nations Treaty to counteract climate change 
(Choeikiwong, 2012). In Thailand, the Enhancement and Conservation of the National Environmental Quality Act (No. 2) B.E. 2561 (The Government Gazette, 2018) (Amendment), which falls under the Ministry of Natural Resources and the Environment, was published in the Royal Thai Government Gazette.

In additions, the consequences of environmental problem not only limit to destroying of natural environmental resources, but also some problems transformed to be the environmental crime or green criminology. Environmental criminology can be basically explained as the study about Crimes against the Environment (Jitsawang, 2016). Damage and seizing the advantages from the natural resources in this world occurred for a long time, but it has just been taken to be the issue in the second half of the 20th century because the trend of interest of world community in the environmental damages and the attempt of a group of criminologists who requested and reflected the point of view against that action being one type of crime (Gottfredson and Hirschi, 1990; Aroonwipada, 2016).

Moreover, it has been pointed out that for Thai society to flourish, individuals should take responsibility in caring for the environment. Thai people are mostly Buddhists, but not everyone in Thailand knows or understands all the Buddhist principles. Lord Buddha himself lived with the natural environment, in a period known as the Rains Retreat or Buddhist Lent, throughout 45 rainy seasons of Buddhism propagation (Somdet Phra Buddhakosajarn, 2017). He also put into legislation many disciplinary rules for monks to live a balanced life in harmony with nature without destroying the environment.

In the face of deforestation, climate change, and extreme flooding in Thailand, Buddhist monks are stepping up as environmental leaders. Although the Buddhist religion typically emphasizes a detachment from society, these monks are acting as environmental advocates through ritual, advising in the political sphere, and agricultural work. By putting the Thai environmental movement on a moral platform, ecology monks are encouraging followers to protect the environment as a religious duty.

\section{Theorical Framework and Aims of this Paper}

The authors of this paper strongly believed that no environmental legislation or policy nevertheless of how effectively it is implemented will stop the ongoing destroying on the environment by human unless mindsets of people who are more likely to become materialism and consumerism person in modern societies would not be changed. Comparing to other similarly studies, the authors attempt to bring the light the Buddhist principals or strategies which could be eliminate or mitigate the environmental problems and environmental crime problems in Thai society and could be the first consideration to create as a practical model to prevent the environmental problems. However, Buddhism's principles are practical and timeless for Thai society as well as other countries. Especially in the current situation of environmental change, it is important for Thai society and individuals to learn and practice the principles of Lord Buddha's teachings. Hence, there are still unknown gap explaining how principles of Buddhist philosophies and concepts related to environmental problems including environmental crime protection or prevention, especially in the Buddhist favour countries like Thailand. The authors felt strong require to pursue library-based exploratory study on this issue.

This present paper argues that even though the principles of Buddhism were founded over 2,500 years ago, they can have an application that is modern, contemporary and practical for taking care of the environment and maintaining the balance of nature. However, the main objectives of this paper are firstly to address literature review on current situations of environmental issues in contemporary Thai society. Buddhism in contemporary and Buddhist principals toward environmental protection should be following discussed. This paper also presents some example of temples in Thailand, where participate in environmental protection by following the Buddhist principals.

In the discussion section, the authors attempt to address how Buddhist disciplines and environmental problem and crime prevention are related and how Buddhist strategies on environmental caring look like. The relationship between Buddhist philosophy and crime, especially five precepts and environmental crime are also discussed to represent how effective Buddhist approaches on environmental perspectives.

\section{Methodology Applying in this Study}

The present doctrinal study is a kind of library based exploratory academic study; hence the research methodology mainly consists of critical analysis of existing secondary literature resources with respect to the theorical framework. The academic work primarily 
includes the collection of literature and reference materials in the form of hard and soft copies. The hard copies included the books, reports, reprint of published research papers, leaflets etc. whereas the soft copies included reliable webpages, research electronic files download from the internet. Information from collected literature was referred and critically analyzed to representing the ideas and issues on environmental problems and environmental crime by the Buddhism philosophy and concept perspectives.

\section{Current Situations of Environmental Issues in Contemporary Thai Society}

The concept of 'society' has been acclaimed in the Western world, where social theory was founded. Plato (427-347 B.C.) explained that people live individually and separately, but they also tend to live together owing to the threat of disaster. Later, French philosopher Auguste Comte (1798-1875), who is regarded as the 'father of sociology', defined 'society' as a development of humankind associated with the law of three stages, and this idea is the origin of social theory (Chantavanich,2012).

Contemporary Thai society is marked by various changes such as population growth, human activity causing environmental problems and the Thailand 4.0 economy, which has led to cultural shifts in family relationships. These factors, which directly influence the environment (Choeikiwong 2012), are detailed in the sections below.

\section{Population Growth}

In Paleolithic for many ten thousand years, there were only about 1-5 million of people living in the world. They lived with eating plants and hunted like animals which were hunters. Until ten thousand million years, people had the evolution to make a living with doing the agriculture and raising animals in small areas without making any effects to the ecology. Until Metal Age, five thousand years ago, people began to know to build metal tools (Learning Center for Earth Science and Astronomy: LESA, 2021). Cutting trees started from that period. However, the numbers of people still increased in the little rate. Until people invented antibiotics in 1357, the death rate was less than the birth rate so much. The numbers of population increased and accumulated since that time. Until the industrial revolution period in 1847, people used machines to manufacture products and facilities. There was the energy consumption in the large quantity, and the numbers of population increased very fast. So, the areas for living and doing the agriculture including the pasturage were needed more. Forests were cut because woods were used as the energy and the production materials. The modern technology like electric chain saws and tractors were used. Cutting trees were done in the short time. The forest areas of world decreased very fast since that time (Learning Center for Earth Science and Astronomy: LESA, 2021).

However, the consequences of increasing world population were not only the change in workplaces, but it affected in a chain which made the world condition changed in many dimensions. We may explain the world condition change occurring from things which can be found in the daily life as follows. When the population increase, the cities are bigger. When the cities are bigger, the houses or workplaces locate in further places. People need to use vehicles to travel. The fuel will be burnt. The greenhouse gas is released into the atmosphere. The world has the higher temperatures. The agricultural areas are changed to be the community areas. The albedo of world surface is changed. When the forest areas became the agricultural areas, burning forest and fields increased. The greenhouse gas was released into the atmosphere. The world temperatures were higher. The human's warehouse system made people to accumulate a large quantity of food in supermarkets. It affected to the food chain and the ecology. When people increased their production needs, every kind of factories released the greenhouse gas. Some kinds of greenhouse gas like FREON (a kind of gas which is the CFC substance) do not affect to the greenhouse effect only, they also damage the ozone in the stratosphere. Living things will be in the danger, and the ecology also is affected and the world population increase.

Owing to Thailand's rapid population growth (Institute for Population and Social Research, 2018) and the immigration of foreign workers, both legally and illegally, urban areas such Bangkok and Pattaya have become densely populated. This has led to a highly competitive environment, a high rate of resource consumption, selfishness and a lack of sense of responsibility for environmental protection and an increasing to offend the environmental crime or does something impacting both direct or indirect consequences to create the environmental crime occurrence such as illegal tree cutting, illegal wildlife trading or even the release of waste into rivers or air which later lead to water and air pollution. 


\section{Environmental Effects of Human Activity}

According to Choeikiwong's six-year study that included 25,000 scientists in over 30 countries, humans are a significant factor in climate change, and, more importantly, environmental protection is the responsibility of everyone, not just certain individuals (Choeikiwong, 2012). Yet, in Thailand, under the excuses of poverty and survival and without a consideration for long-term consequences, many people have engaged in deforestation, forest trespass or wood smuggling. According to the Royal Forest Department's statistics, the forest area in Thailand continuously declined during the period of 1973-1998, although there was an increased growth rate from 2000-2014. This is because, since 1999, the Thai government has had awareness of the significance of forest resources. As a result, it decreased deforestation and started reforestation projects (Royal Forest Department, 2014).

Moreover, populated urban residential areas near rivers were mostly constructed by encroaching on the land for public interest. Many people dump garbage and waste into the rivers, affecting the environment of the community and society overall. Thus, human behaviour has direct negative influences on nature.

Although Thailand passed the Enhancement and Conservation of the National Environmental Quality Act (No. 2) B.E. 2561 (The Government Gazette, 2018). Amendment as an effort toward environmental protection, the law appears impractical to implement in some organisations or regions. Since the law merely directs responsible officials to perform their duties, by itself, it is not adequate for natural resources conservation and preservation or environmental protection.

\section{The Importance of Forest Resources}

Forest resources play an important role in the entire system of natural resources that mutually support. They are generally called the ecology. For understanding the value of forest resources, Siripatanadilox (1992) stated that the forest that as the law, the forest means areas which aren't possessed legally. They are defined into many kinds of forests, such as National Reserved Forests, Forests being ready to be reserved forests, National Parks, and Wildlife Reserves. As the general meaning, forests are areas covered with plants like trees, bushes, grasses, or other plants which aren't agricultural plants. For the ecology, it is fond to call forests to be vegetative cover type. They can mean the stony grounds covered with mosses and little plants, meadows, and big forests with 50-metre-high trees. Besides, the forests give benefits directly and indirectly to everything in the world.

It is clear that forest resources are very important, as they are the biggest and most important sources collecting heredities of creatures. There also are several plants and animals living in forests which humans have never known. They are the sources improving heredities of plants and animals and the sources of ingredients for medicines. Forests have also been the resources which humans used for building towns and communities since the primitive age. They help to absorb water and to slow down the flood. These are the importance and direct and indirect advantages. So, the Thai government in every period give the importance to the national policies of forests. It defines $40 \%$ of areas in Thailand to be the forest areas. (Channarong, 1992).

\section{The Situation of Forest Resources and Conservation Forest Areas in Thailand}

The situation of forest resources in Thailand should be concerned as time passed. In 2017, Thailand had the forest areas about 102.16 million Rai or $31.58 \%$ of all areas. They were stable when being compared in 2016. When considering in the last 4 years (20142017), it found that the decreasing rates of forest areas were better because the government gave the importance to increase the forest areas for achieving the targets defined in National Forest Policy B.E. 2528, The National Economic and Social Development Plan Volume 12 (B.E. 2560-2564), and the national reform plans for natural resources and environment of which the targets were to increase the forest area proportion to be $40 \%$ of all areas at least (Office of Natural Resources and Environment Policy and Planning: ONEP, 2019). However, Thailand still has the conservation forest areas. It shows that plentiful areas are still kept well as the following details. Conservation forest areas are consisted of national park areas, wildlife sanctuaries, non-hunting wildlife areas, botanic gardens, and arboretums which Department of National Parks, Wildlife, and Plant Conservation is responsible for. In 2017, there were 458 places of which the areas were 69,359,906.51 Rai. When considering in the last 6 years (2012-2017), it found that the conservation forest areas tended to increase. (ONEP, 2019). 


\section{National Reserved Forest Areas}

The national reserved forests which Royal Forest Department is responsible were found that, in 2017 , there were 1,221 national reserved forests; the areas were 143,925,404.30 Rai (attached with Ministerial Regulation) and about 146,344,407.26 Rai (calculated by the GIS system). It found that the national reserved forests in the north had the most areas; the next ones were the Northeast region, the Central region, the South region, the West region, and the East region in order. The forest numbers in the South region were the most; the next ones were the Northeast region, the North region, the Central region, the East region, and the West region in order. When considering the last 10 years (2008-2017), it found that the numbers of national reserved forest areas (attached with Ministerial Regulation) were stable (ONEP, 2019).

\section{Encroached Forest Areas}

The loss of forest areas in Thailand comes from many causes. The reforestation is one important reason. Forests are invaded and cut trees. Besides, forests are reclaimed for agriculture and dwellings including for tourism. From considering the statistics of breaking forestry law cases in 2017, the national forest areas were invaded about 107,932.90 Rai, increasing 1,649.46 Rai from 2016 when the encroached forest areas were 106,283.44 Rai. The national reserved forest areas were invaded about 35,607.82 Rai, decreasing 14,445.40 Rai from 2016 when the encroached forest areas were 50,053.22 Rai. When considering during the last 10 years (2008-2017), it found that the encroached forest areas tended to increase (ONEP, 2019).

\section{The Numbers and Areas of Community Forests}

Royal Forest Department (2018) has arranged the community forest projects and supported the community forest management since 2000 until present. It arranged in target villages around the national reserved forests within $5 \mathrm{~km}$ of radius so that communities were the center of management, control, care, or maintenance forests; they also developed the environment and forests and made the community power concurrently along the way of sufficiency economy. The operation results on $30^{\text {th }}$ June 2018, there were 11,114 villages in the community forest projects. Their areas were about 6,085,188 Rai $1 \mathrm{Ngan}$ 58 Square wa. In the North region, the community forest areas were the most; they were 3,863,473 Rai 43 Square wa; the next ones were in the Northeast region, the areas were 1,411,749 Rai 3 Ngan 19
Square wa, the areas in the Central region were 567,891 Rai 1 Ngan 35 Square wa, and the South region had the areas 214,575 Rai 2 Ngan 18 Square wa in order (ONEP, 2019).

\section{Family Relationships}

As Thai society has entered the Thailand 4.0 era, the economy is focused on innovation (Chanocha 2017). A material culture has emerged, with effects on people's mentality and interactions in the workplace, environment and home, apart from the traditional influence of religion. For instance, the word 'phubbing' describes the behaviour of people who ignore their companions, and sometimes parents as well, in favour of using cell phones or other electronic devices. In addition, sometimes parents are not able to teach their child properly because the child has already learned about the subject outside the home or through technology. Thus, education and behaviour, which had formerly been shaped early on by the family, are under the influence of modern changes. This may lead to social problems in family relationships.

The family has long been the most important institution in Thai society. With strong and healthy families, the community and society stay strong and healthy as well. The Moral Promotion Centre encourages parents to teach their children about the five precepts, kindness and generousness and to engage them in moral development activities or take them camping to create a conscience for love and understanding others (Moral Promotion Center of Mahidol University, 2010). If the family is weakened, how can family members be expected to function well in society?

\section{Buddhism in Contemporary Society}

Lord Buddha established his religion in what is now India and Nepal. Jambudvipa was divided into 16 large cities (Somdet Phra Buddhakosajarn, 2017). Many rich people lived there, such as Chadith-setthi, Anadhabindhika-setthi and Visakha. People in Jambudvipa were divided into four castes or varna by occupation: 1) Kshatriya: rulers, including high authorities such as the Minister and Purohit; 2) Brahmana: people who had the duty of performing ceremonies and teaching, such as the six gurus; 3 ) Vaishya: merchants, agriculturalists and ordinary people and 4) Shudra: labourers, who were loathed by others in the hierarchy. A person had to perform duties on the basis of caste and live with other members of 
the same caste. Marriage between members of different castes was prohibited. A child of a person from the Shudra caste and a person from the Vaishya caste was considered Shudra. This type of discrimination causes misery particularly for members of the Shudra caste.

In this context, however, Lord Buddha established the Buddhist religion without discrimination of caste, gender or age, as such differences were not obstructions for understanding his teachings. Lord Buddha's teachings also addressed the environment in terms of the compatibility of life and nature.

Although Lord Buddha's teachings were given over 2,500 years ago, when there were not many environmental problems, Lord Buddha and his followers lived in harmony with nature. That is, they cultivated gratitude without destroying or exploiting natural resources for their own benefit. Moreover, some parts of Buddhist doctrine relate to the good of the natural world and its significance. Importantly, these doctrines and disciplinary rules are deemed natural law; Buddha was merely the founder of the religion who then spread the ideas. Furthermore, Buddhism and Thai society developed a close relationship as early as the $5^{\text {th }}$ century (Dokbua 1999).

Pursuant to the explanation above, Lord Buddha's teachings are universal concepts that describe natural laws with no discrimination by race or gender. In this way, the doctrine can be considered timeless, and it is no surprise that Thai society has held the traditions and beliefs of Buddhism over a long period.

\section{Buddhism Principals Toward Environmental Protection}

In Lord Buddha's lifetime era, people did not face environmental problems on the same scale as today, but Lord Buddha still created disciplinary rules-which are deemed universal and practical-for the monks, nuns and everyone generally, for guidance purposes. Apart from these disciplinary rules, he also formulated the kindness principle, which explains that people should not destroy things but provide support. The sections below further explain the Buddhist principles that relate to environmental protection.

In Thai society, environmental conservation is regulated by the Enhancement and Conservation of the National Environmental Quality Act (No. 2) B.E. 2561 (The Government Gazette, 2018) Amendment, which specifies that everyone's cooperation is needed.
Moreover, since Buddhism is the main religion in Thailand, environmental protection strategies or policies should be compatible with the concepts in the Buddhist Scriptures, also known as "Tripitaka".

Several environmental problems or environmental crime prevention perspectives should be found in the Tripitaka in the term of Lord Buddha' teaching philosophy. In this section, such philosophies should be reviewed and discussed as following:

\section{The Vinaya}

The Vinaya has a long history since Lord Buddha's lifetime era. During the period that Lord Buddha stayed in a Buddhist monastery during the Lord Buddhist Lent in Waerunchara according to Waerush Brahman's request, during that period, Waerunchara had the famine and the dearth. Monks who stayed in a Buddhist monastery during the Buddhist Lent difficultly relied on brown rice of merchants who stayed during the rainy season in this city. Lord Buddha praised many monks who fought against the difficulty, and they did not find the happiness dishonestly. Although Phra Mokkhallana advised to receive food offerings in other cities, Lord Buddha did not allow him. At that time, Phra Sareeboot who saw the persistence in the religion asked Lord Buddha. During that period, Lord Buddha said about the adherence and the disregard in the religion that the discipline enactment and the prayer in the middle of every month made the religion to persist. If they did not do that, the religion would disappear. When the story continued like this, Phra Sareeboot told Lord Buddha to enact the discipline, but Lord Buddha said that the time had not arrived yet because during that time, there were not many monks, gain and honors, and his followers were Buddhist saints. They were the cause to enact the discipline (Mahamakut Buddhist University, 2014).

So, it was the source that when Lord Buddha enacted the discipline, he did not do nonspecifically. He had to use the suitable causes and factors, then he would enact the discipline as the cause enacted in the first discipline. The story was that at the place not far from Vaishali, there was a house named Kaluntha. In that house, there was a son named Sutin. He listened the dharma from Lord Buddha and asked to be ordained. Lord Buddha did not allow him because Sutin had not been allowed by his father and mother yet. So, Sutin came to his house to ask for his parents' permission, but he was not allowed. Sutin requested with many reasons, but he did not succeed. Until his 
friends helped him to talk with his parents, he could be ordained. Next, Phra Sutin came to visit his parents, they requested him to leave the Buddhist monkhood, but he did not agree. So, his parents asked Phra Sutin had a sexual intercourse with his ex-wife so that they had a son to be descended. Phra Sutin had a sexual intercourse with his wife because the discipline saying that having a sexual intercourse was the mistake had not been enacted. Next time, Phra Sutin became thin. All monks knew and told Lord Buddha. Lord Buddha set up the monks' meeting. He inquired, blamed, and enacted the discipline forbidding monks to have a sexual intercourse. He ordered to have the offence and the gravest transgression (Mahamakut Buddhist University, 2014)

That's why Phra Sutin did not resist against the discipline because it was the first discipline. So, it was regarded that Lord Buddha enacted the discipline, there had to be monks making the mistake, and they were blamed at first. Then, Lord Buddha would set up the monks' meeting and inquired by himself. When he found that it was the truth and the wrong thing, monks should not do, he enacted the discipline. The penalty was defined also so that monks did not do again. If any monks resisted against the discipline, they received the penalty as defined. This is the origin of the discipline enactment. Besides, followers could not claim that they did not know the discipline. As the story of Phra Shappuckkhee, he claimed that "We had just known at this time that this dharma came in Suttas" (Mahamakut Buddhist University, 2014). Lord Buddha punished monks with the petty offence who pretended that they did not know anything.

The Vinaya is one of the three parts in the Tripitaka, which are as follows: 1) Vinaya Pitaka: regulatory framework for monks and nuns, 2) Sutta Pitaka: regulatory framework on general preaching and 3 ) Abhidhamma Pitaka: doctrines and important dharma (Bhunyanuphab, 2011). This article emphasises the Vinaya since its doctrine demonstrates that Lord Buddha was well aware of environmental protection and legislated conduct for monks and nuns accordingly. The relevant concepts include prohibitions on dumping waste, deforestation and killing animals, which relate to the principle of kindness. These are explained below.

\section{Prohibiting Dumping Garbage and Waste into the River}

Prohibitions included swimming in the river; pouring water containing living beings; and defecating, urinating or spitting in the green grass (plant) or the water (Bhunyanuphab, 2011). Sankarawashudra describes Lord Buddha's response to purifying bathing (Mahamakut Buddhist University, 2014). In Lord Buddha's time, people in India believed that bathing in the Ganges was purifying since the Brahmin said that it could take one to heaven after death. However, Lord Buddha explained to a Brahmin at the river that he could not go to heaven since there were many animals and species living in the river, and they had spent more time in the river than the Brahmin had; therefore, there was no space for the Brahmin in heaven.

Lord Buddha was aware that people dumped garbage, human waste and other things, including dead bodies, into the river, which could cause pollution. It also meant that a person who bathed in the river was likely to contract germs. Under these circumstances, taking away sin and impurity by bathing in the river was irrational.

\section{Prohibiting Deforestation and the Killing of Animals}

There was a disciplinary rule against deforestation, and anyone who broke the rule could be liable to punishment. Digging in the ground was also prohibited since such action could kill animals that lived under the ground. Pouring water that contained living beings was prohibited as well. As for monks, they were prohibited from eating nine types of meat (i.e. elephant, horse, domestic dog, snake, lion, Bengal tiger, leopard, bear, and fox meat), and those who violated the rule would be liable to punishment (Bhunyanuphab, 2011).

As shown in the paragraph about plants, the first discipline, it was about the Arnwee monk. Lord Buddha stayed at Akkarnwa Stupa near Arnwee. Arnwee monks helped each other to do the construction. They cut plants by themselves or ordered others to cut. Living things in that area were in trouble. They were blamed by general people. When Lord Buddha knew, he asked and blamed that "Everyone thought that living things lived in trees. Your actions were not done for the faithfulness". After that he enacted the discipline to punish with penalty offence to monks who damaged plants (Mahamakut Buddhist University, 2014). In the classification discipline, plants which monks were forbidden to damage were clearly defined. They defined the plant appearance as follows.

1. Plants came from rootstocks, such as Curcuma, Ginger, Sweet Flag, Galangal, Cyperus Rotundus Linn, etc. 
2. Plants came from trunks, such as Sacred Flag, Fiddle-leaf Fig, Long Pepper, etc.

3. Plants came from buds, such as Sugarcane, Bamboo, Cattail, etc.

4. Plants came from treetops, such as Morning Glory, Lemon Basil, Bai-ya-nang, etc.

5. Plants came from seeds, such as Rice, Peas, Sesame, etc. (Mahamakut Buddhist University, 2014).

This was another discipline which shown Lord Buddha's vision in the position of the highest leader during that time. He clearly defined the appearance of plants which monks were forbidden to damage. All of 5 kinds which he forbids could be said that they were all species which were in that period. It was the noticeable point for the present time that we found most of monks living in forest areas because villagers in the nearby areas cut and cleared other areas and used in the agriculture. So, the areas where monks stayed in a Buddhist monastery during the Buddhist Lent still were the forests. There were not only the areas in the upcountry, we could notice that temples or houses of priest in the downtown had plants covering all areas in temples. When we entered into those places, we felt comfortable, happy, and peacefulness. There might be someone opposing this idea, but in general, the naturalness could be found in the temple areas (Ketsil, 2020).

Besides, Lord Buddha forbid to dig or order others to dig soil because it might kill animals if those tools harmed animals. He forbids to water or order others to water grasses or soil with water having animals. It appeared in the paragraph about lie. It was about an Arnwee monk. During that period, Lord Buddha stayed at Akkranwa Stupa near Arnwee. At that time, Arnwee monks helped each other to do the construction. They dug by themselves or ordered others to dig soil. They were blamed by general people that they did against monks' custom. Lord Buddha asked, blamed, and he enacted the discipline that monks dug soil by themselves or ordered others to dig soil, they had to be punished with penalty offence (Mahamakut Buddhist University, 2014). Indian people during that time believed that everything was the organism or the living things. Especially when they are monks, they should not do as layman. It was important that they had not to exploit living things living in soil. This discipline was enacted so that there was not any sin being committed such environmental crime continually (Ketsil, 2020)
For forbidding to kill animals, the story was that in one period, Lord Buddha stayed at Phra Cheatawan, the monastery of Anathabinthika, a wealthy person, near Phra Nakhon Sawatthee. At that time, Phra Uthayee who was an archery player in the past did not like crows. He shot them, cut their heads, and pierced in the javelin. When monks saw, they blamed and told Lord Buddha. Lord Buddha called monks to have a meeting for asking. Phra Uthayee accepted that it was true. Lord Buddha blamed him and enacted the discipline that when any monks killed any living things, they had the penalty offence (Mahamakut Buddhist University, 2014). We could see that Lord Buddha enacted the discipline about forbidding to kill animals in every level of precepts like five Precepts or five basic Buddhist precepts of moral practices, eight Precepts, and ten Precepts. The details are as follows. Killing animals which was regarded to be against this discipline completely had to consist the following compositions. Those animals were living things. (Animals meant human, but they did not include plants.) Those animals were known that they lived. (If it was not sure whether those animals still lived or not, the guilt was smaller.) There were thoughts or the intention to kill those animals. There was attempt to kill animals, and they died because of this attempt. If animals did not die or died because of other causes, the guilty was smaller. The occurring sin was much or small depending on the completeness along these five rules, the qualification of the dead, and the used attempt as follows.

Moreover, the more attempt was used, if killers spent more time for planning and preparing, the more the $\sin$ was because the mind had to have much power, and that temper was taken for a long time. So, killing large animals had more sin than killing small animals. If the dead had much favour for killers, the sin increased. Killing which had the sin the most was killing their own fathers, mothers, and Buddhist saints (Thammachote, 2016).

As shown in above explanation, it is said that killing animals' compositions consideration to be against the Buddhist precepts discipline is look like the homicide offense compositions in criminal law. Both two offenses, even killing animals or killing human, not only violate the criminal law or other related law such as forest law, wildlife conservation and protection act, but such offenses also against Buddhist precepts discipline and being a sin. 


\section{Prohibiting Lighting Fire}

According to the $6^{\text {th }}$ discipline in the liquor paragraph, it is written regarding the banning to light fire to warm oneself. The story started since Lord Buddha stayed at Phedkala Marukkhathayawan near Mueang Soong Suman Kira in Phakkha Region. When the winter came, monks in Soon Suman Kira lighted fire for warming themselves. There was a snake receiving the heat, so it went out a log and bit monks. All of them broke up and escaped. Monks and simple people blamed until Lord Buddha knew, and then asked, and complained Soon Suman Kira. Later, Lord Buddha enacted a discipline that if any monks lighted fire by themselves or ordered others to light fire for warming, they should get the penalty for such offense. However, after time passed, Lord Buddha allowed sick monks to light fire and warm themselves. (Mahamakut Buddhist University, 2014)

Lighting fire was the main point because monks in Lord Buddha era lived and stayed in forests during the Buddhist Lent. Lighting fire might spread and became forest fire destroying wildlife animals and environment. It showed Lord Buddha's omniscient. It could be applied in the present time, such as the dust problem which caused from burning agricultural scraps and cooking food which made smoke and led to the PM2.5 problem which was over the standard value. If everyone recognized the occurring effects and took the principle of this discipline which was enacted by Lord Buddha, the occurring problem might be relieved.

\section{Kindness}

Lord Buddha suggested the principle of kindness in Fourt-Brahmavihara as follows: 1) loving-kindness (metta) is wishing that others have happiness; 2) compassion (karuna) is wishing for others to be free from sorrow; 3 ) empathetic joy (mudita) is feeling glad for others' achievements and 4) equanimity (upeksa) is being calm (Mahamakut Buddhist University, 2014).

Loving-kindness means wishing everyone to be happy. The happiness was needed by everyone. It could occur body and mind, such as the happiness from having assets, from spending capitals for consumption, from not having debts, and from working without wickedness, etc.

Compassion means wishing everyone to leave from suffering. The suffering was the thing exploiting, and the unhappiness occurred body and mind. It came from many factors. Lord
Buddha concluded that there were 2 big groups of suffering as follows.

(2.1) Suffering from the condition or from changing naturally the body, such as birth, sickness, elderliness, and death. All living things in the world had to face with body changes inevitably. All of them were called physical pain.

(2.2) Temporary suffering or mental suffering occurred from the external cause, such as when we wished something, and we could not fulfill our hope, we would have the suffering. When we faced with undesirable things, there will be the suffering. When we were separated from beloved things, we would have the suffering. All of them were called mental pain.

(3) Sympathetic joy means the gladness when others received good things. The word "good" in this place meant having the happiness or the advance. The gladness when others received good things meant wishing others to have the happiness and the advance without the envy. The envy was the unhappiness. The anger and the distraction always happened when seeing others receiving better things than their own, such as when we saw a friend getting dressed neatly and a teacher praised him. We envied him, so we disturbed him by taking chalk scraps, mud, or ink to coat his shirt or trousers to be dirty. We had to practice ourselves to have the sympathetic joy so that we would have the friendship and have the good relationship with others easily and profoundly.

(4) Equanimity or the ignorance means the neutral mind because it considered that what goes around, comes around as the karma rule which was that anyone did anything, it reacted to doers. When we saw that someone received the retribution in the bad way, we should not be happy or aggravate him. We should have the goodwill. We should try to help others to be free from suffering correctly along the moral (Nyanaponika, 2013).

Thus, the rules described above constitute universal doctrine because they were created for the purpose of kindness and avoiding destruction. Anyone can practice them, but Lord Buddha instituted the disciplinary rules especially for monks and nuns, who had devoted their lives for Dharma. The disciplinary 
rules were similar to the law, which meant that if monks and nuns violated the rules, it was possible that they were simultaneously violating the law. In addition, the Vinaya emphasised intention; for instance, the prohibition on killing was detailed, and one's intentions-namely, whether one had killed the animal intentionally or not-were taken into consideration. In contrast, the law was not that detailed: an eyewitness account could lead to the assumption that one had committed a crime. If people could comply with Lord Buddha's disciplinary rules, the law would not be necessary. However, since many people violated the religious rules, enacted laws were needed. Monks and nuns were expected to be role models for others in society.

\section{Temples' Participation in Environmental Protection}

Owing to the rapid change of social context from Lord Buddha's era to the present day, Buddhism has also changed, as can be seen by the different interpretations of the principles and concepts. For instance, a monk in Japan could marry (Chumsai $\mathrm{Na}$ Ayudhya and Dhammasakiyo, 2015). In addition, monks in Thailand can be learners, practitioners or enlightened persons. To maintain Buddhism and keep updated with technology, innovation and globalisation, they sometimes have to change their mind-set as well. Moreover, monks protect the environment by applying practical measures beyond those described in the Tripitaka. The activities of three temples are described below.

\section{Wat Pavaranivesh Vihara Rajavaravihara (Bangkok)}

Wat Pavaranivesh Vihara Rajavaravihara (or Wat Bowon for short) was originally called New Temple. It was built by the Heir Apparent in the era of King Rama III, and King Rama III appointed King Rama IV as the abbot of the temple when King Rama IV was ordained. The temple was later called Wat Pavaranivesh Vihara Rajavaravihara (Nawikkamun, 2006). It had a relationship with Wat Bowonniwet School in the same area. In addition, the temple was a place model for a wastewater aerator creation, which was one of the Royal Initiative Projects of King Bhumibol Adulyadej. The wastewater aerator was built for sewage treatment, a process that involved injecting the wastewater with oxygen so that the water would be safe enough to use. King Bhumibol Adulyadej was granted the patent for the project on February 2, 1993 and became the world's first monarch and the only Thai monarch to be granted a patent. In addition, King Bhumibol Adulyadej was ordained and stayed at Wat
Pavaranivesh Vihara Rajavaravihara for a period (21st April Capital 2013), and the temple is considered the dwelling place of Somdet Phra Nyanasamvara Somdet Phra Sangharaj, also known as Chareon Suwannano (Osathanugrah, 2006). Mahamakut Buddhist University is also located in the same area.

Wat Pavaranivesh Vihara Rajavaravihara is an important temple in Thai royal history since several kings had their ordination there. When visiting with family, people tend to reminisce about the Thai monarchy. Furthermore, Wat Pavaranivesh Vihara Rajavaravihara has a serene and calm atmosphere with an abundance of trees and a beautiful 'ubosot' (ordination hall). Although the air outside the temple is highly polluted, one can breathe comfortably inside the temple area. Moreover, large fish swim in the canal, which is evidence of good environmental quality.

\section{Wat Nyanavesakavan (Nakhon Pathom)}

Wat Nyanavesakavan is located in Nakhon Pathom province, and it was the dwelling place for Phra Somdet Buddhakosajarn (Somdet Phra Buddhakosajarn, 2017) during the rain retreat. The temple is located in one of the central provinces of Thailand, not far from Bangkok. There are many routes to Wat Nyanavesakavan, but the most convenient one is Phutthamonton 5 Road. The appearance of the Wat is different from other temples, as it has many ivies and a variety of trees and plants that make it resemble a forest. In the temple area is the library of Thammasapa, a pool and a white double-story ubosot, which provide a sense of tranquillity. Furthermore, in Wat Nyanavesakavan, there is no donation box, no Kau Cim and no activity of placing a gold leaf onto the Buddha statues. However, the temple provides many activities for free, such as Dharma talks and meditation courses. Therefore, it is an appropriate destination for a family trip.

Evidently, Wat Nyanavesakavan had good management since the researchers did not observe any trash in the temple area. Wat Nyanavesakavan is regarded as the city model of tranquillity and relaxation for people who live in the metropolis. Additionally, it serves as a centre of the community without having a negative environmental impact. That is, the temple helps conserve the environment at a good level.

\section{Wat Khao Banchop (Chanthaburi)}

The atmosphere of Wat Khao Banchop is natural and soothing, with shady trees and abundant natural 
resources. The temple was built on the basis of preservation and conservation of natural resources, including trees, streams, aquatic animals and wildliferather than on the basis of natural resource depletion. No one dares to trespass in the temple territory or trap the aquatic wildlife nearby. Consequently, the forest and wildlife are abundant. In addition, under the leadership of the abbot Phrakhu Dhammadhorn Boonkara Toonthummo (Uttamapunyo 2018), monks and villagers planted trees near the canal to prevent soil erosion caused by water erosion. Wat Khao Banchop also provides a place in its ubosot for meditation retreats and visitors searching for a relaxing place, fresh air to improve their health and energy or a break from work, city pollution or social problems.

If the urban metropolis followed the example of Wat Khao Banchop, a better relationship with the environment could be realised. A specific plan could recognise Wat Khao Banchop as a role model for change. Change must begin with personal residences before advancing to larger parts and, eventually, to all sectors and relevant persons. Even so, as material culture continues to develop and cultural shifts take place, it is necessary to observe Wat Khao Banchop in terms of whether there are environmental impacts of its activities.

\section{DISCUSSION}

\section{Concept and Perspective of Buddhism Towards Crimes}

Criminology is the scientific study of the causes of wrongdoing and ways to prevent wrongdoing known as crimes. Therefore, criminologists need to understand what the causes of crimes are, which factors lead to decision of a person who commits a crime including how to prevent a crime, which are the questions and goals of studying criminology that requires interdisciplinary solutions as a condition of the study in order to achieve the goals in controlling and preventing crimes.

Religion is a social institution that plays a part in preventing moral wrongdoing or helps suppress or delay the occurrence of wrongdoing and crimes in the form of informal social control one way or another. Religion participates in inhibiting minds of people who are going to violate moral principles or commit wrongdoing. Any person has a religion as a spiritual anchor, he/she will have a smaller opportunity to commit wrongdoing (Chapilanan, 1994). Besides, laws that are most likely originated from religious provisions, belief and value or respect paid to a religion are meaningful and have influence on a way of life of people in society (Phrakhru Atthajariyanuwat, 2017). As a consequence, religion plays an important role in an increase of decrease in the number of crimes. Religions and crimes are associated to each other.

According to Buddhism, an opinion is given that both humans and animals are basically afraid of death. People should give importance to the value of living at every level equally. Attacking, exploiting, killing are bad deeds that can be formed to be crimes and turn to be criminal behavior at the end, which are things that Buddhism opposes and prescribes Buddhists to refrain from doing bad deeds for the benefit of peace at an individual level in the first place, having an effect on the society at a structural level. In addition, Buddhism identifies consequences of committing crimes as persons who commit crimes need to get in trouble as they will be punished in accordance with criminal law and receive mental suffering at the same time. In this regard, Buddhism pays respect to living one's life that should not be violated since all animals do not like to be exploited and are afraid of death. Moreover, crimes are damages caused by bad deeds or evils from which Buddhists and everyone should refrain for their own peace and peace of the society.

\section{Five Precepts, Crimes, Environmental Crimes}

Buddhist five precepts refers to guidelines for ethical living are integral to Lord Buddha's path of practice including refrain from killing, stealing, sexual misconduct, false and harmful speech, and intoxication. It could be said that these five guidelines are essentially apply to crime prevention strategies especially environmental crime approaches. The authors would represent how concept of five precepts related to environmental crime and environmental caring in this section.

1. 'Panatipata veramani sikkhapadam samadiyami' or 'abstrain from killing' is the first of the five precepts which is the Buddhist guidelines for an ethical life to refrain from taking life, often phrased as a vow not to kill living creatures. In view of criminology, it can be seen that the first precept is associated with a crime known as violent crime or serious force or threat against life and body, ranging from common assault to murder (Lydia et al., 1994). Violation of the first precept leads to an assault committed with the 
intent to cause a seriously bodily injury, known as aggravated assault or an assault with the intent to murder, known as homicide. The first precept is a basic Buddhist principle related to crimes against life and body according to criminology and it is sometimes classified as environmental crime committing.

2. 'Adinnadana veramani sikkhapadam samadiyami' or 'abstrain from taking what is not given' is the second of the five precepts which is the Buddhist guidelines for an ethical life to refrain from taking what is not given, often simplified to not stealing. This precept covers all the illegal behavior one would expect, such as burglary, shoplifting, fraud, and counterfeiting, as well as mundane activity like wearing a sibling's clothes without asking permission. It is related to crimes against property (Lydia et al., 1994) involving the taking of property or money in a professional or occasional manner depending on a situation, opportunity in destruction. Crimes against property is a category of crime that includes burglary, motor vehicle theft, theft, arson, vandalism, shoplifting including embezzlement and corruption. Therefore, violation of the second precept is committing a crime according to a criminological explanation.

3. 'Kamesu michacara veramani sikkhapadam samadiyami' or 'refrain from sexual conduct' is the third of the five precepts which is the Buddhist guidelines for an ethical life to refrain from sexual misconduct. It can be compared to sex-related offences, sexual crime or rape. In general, sexual activity, most often sexual intercourse, that is forced on another (men, women and transgender) without the person's consent or against the person's will is rape, which is considered a criminal offense (Lydia et al., 1994). In this regard, it can be seen that the third precept covers all sexual crimes and violation of the third precept will lead to committing a crime.

4. 'Musavada veramani sikkhapadam samadiyami' or 'abtrain from false and harmful speech' is the fourth of the five precepts which is the Buddhist guidelines for an ethical life to refrain from false and harmful speech, often simplified as not lying.

According to Buddhism, Lord Buddha blamed lying to someone and deceiving others as shown in the Tipitaka Volume 25 Thai version
Kuttokanikai Ititwuttaka Musavadasuttra, item 203 page 211 that

".........those who are named as liars can do evil things..."

It means that Buddhism considers that lying is a fundamental part of do other bad deeds including committing a crime such as forgery, gathering of people to form a gang to deceive or cheat others out of something, known as fraudulence. These actions are violation of the fourth precept, which inevitably lead to a crime.

5. 'Suramerayamajja pamadathana veramai sikkhapadam samadiyami' or refrain from intoxicants' is the fifth of the five precepts which is Buddhist guidelines for an ethical life to refrain from using intoxicants, which are said to cause carelessness. While the phrasing in Pali, the language of some of the oldest Buddhist texts, undoubtedly refers to alcohol, beliefs about whether this precept allows for any form of alcohol consumption or drug use differ from school to school and even from teacher to teacher. Perhaps because of ingrained cultural habits of social drinking and the association of alcohol with the good life, the fifth precept is often not followed to the letter. In addition to alcohol drinks, it includes all types of drugs that cause unconsciousness leading to making a quarrel, argument or a fight. In addition to committing a crime, people perhaps become victims of a crime. According to criminology, drug use is a crime; victimless crime or a person who commits a crime is the victim of the crime.

Most traditional Theravada Buddhists find marijuana, hallucinogens, and other recreational drugs to be clear violations of the fifth precept, comparing to opinion among Mahayana and Zen Buddhist groups varies. Mahayana Buddhists believe that hallucinogens can serve as spiritual aids has been popular in the West, since many current Western Buddhist teachers came to Buddhism during the drug-exploratory counterculture of the sixties. This view lost favor in ensuing decades but is once again in vogue today (Mahamakut Buddhist University, 2014 Phrakhru Atthajariyanuwat, 2017). On the other hand, some teachers, especially Zen Buddhist teachers understand the fifth precept to mean refraining from any addictive or compulsive behavior that intoxicates the mind, such as pornography, gambling, shopping, overeating, excessive exercise, unskillful use of the internet, and 
Table 1: A Relationship between Violation of Buddhist Five Precepts and Types of Crime ${ }^{a}$

\begin{tabular}{|c|c|}
\hline Violation of the five precepts & Crimes Type \\
\hline \hline The first precept: Exploiting, attacking life and body & Violent Crime, Assault, Homicide, Environmental Crime \\
\hline The second precept: Burglary, fraudulence, stealing & Property Crime, Burglary, Robbery, Environmental Crime \\
\hline The third precept: Sexual misconduct, rape & Sexual Crime, Rape, Environmental Crime \\
\hline The fourth precept: Lying, cheating & Professional Crime Fraudulence Environmental Crime \\
\hline The fifth precept: Alcohol drinking, drug use & Victimless Crime, Drunker Drug User \\
\hline
\end{tabular}

${ }^{a}$ Phrakhru Atthajariyanuwat (Suthep Srithong). (2017). Buddhist Criminology: Buddhist Paradigm to Explain Crimes. RTNA Journal of Social Science, Humanities and Education. Vol. 4 No.1 January - December 2017

overconsumption of TV, and other media. Even Buddhist practice, when undertaken obsessively, can be an intoxicant in this view.

According to the Table 1 showing the comparison between the violation of the 5 precepts and crimes as mentioned above, the basic of almost all crimes comes from violation of the precepts. However, to identify the difference or criteria in measuring violation of the precepts and crimes should take some points into consideration, namely, some behavior that seems to violate the precepts may not become a crime; for example, drinking alcohol is considered violation of the five precept but it is not treated as a crime. However, such behavior is a basic leading to a crime. Violation of any precept is a fundamental part or tendency to committing a crime.

Comparing to the environmental crime perspective, environmental crimes or known as green crimes is from violation of the first to the fourth rules. According to the Table 1, environmental crimes can be seen from illegal trade of wildlife, wildlife hunting and killing to trade animal carcasses, etc., or deforestation which represents violation of the first precept including exploiting and killing life and animals. Some environmental crime committing such as stealing temple properties or properties in historical sites, cutting the head of Buddha statues, stealing precious Buddha statues and antiques for illegal trade are considered as violation of the second precept in term of burglary, fraudulence, stealing. Additionally, violation of the fourth precept infers lying, deceiving, cheating among shrewd merchants who buy those stolen goods and deceive customers in buying accordingly. The way that some humans sexually harass on some animals like dogs by claiming as personal sexual preferences is considered as violation the third precept, and animal abuse.

Furthermore, an interesting point as of today is the way that shrewd vendors catch various types of animals like birds and fish and cage them for selling to people who wish to make merit by releasing animals from the traps. It is still a controversy whether it is a method to make merit or destroy environment considered to be an environmental crime with clearly illegal action. Consequently, in order to study Buddhist environmental management, it is necessary to study environmental crime or green crime for the benefit of connecting relationship between environmental crime and Buddhist concept that will lead to a guideline to prevent and suppress environmental crimes according to Buddhism which is a part of Buddhist environmental management in an efficient manner.

\section{How Buddhist Philosophy Plays Important Role to Environmental Protection}

In Lord Buddha's lifetime, people did not face environmental problems on the same scale as today. Yet even though environmental concerns were not salient, Buddha legislated disciplinary rules for monks to live in nature without causing environmental destruction. On the other hand, currently, Thailand is operating in an economic development model called Thailand 4.0, in which environmental problems are a major concern. All citizens need to cooperate in order to conserve the nation's natural resources and sustain a clean environment.

Buddhist philosophy does not focus on material possessions. In addition, the ideas and doctrine are timeless (called Akaligo in Sanskrit). Yet technology and communication are changing Thai culture, and the Thailand 4.0 era emphasises material wealth as the indicator of a person's success or achievement. This situation stands in contrast to the caste system of Lord Buddha's time, when a person's rights were limited by social norms.

The discipline enactment about the environment which Lord Buddha enacted for over 2,500 years ago 
Table 2: Conclusion of the Discipline Enactment about the Environment being Applied for the Environmental Conservation

\begin{tabular}{|c|c|c|}
\hline $\begin{array}{l}\text { The discipline enactment about the } \\
\text { environment }\end{array}$ & Details & $\begin{array}{l}\text { The benefits for natural resources } \\
\text { and environment }\end{array}$ \\
\hline Forbid to leave dirtiness into rivers. & $\begin{array}{l}\text { Forbid monks to defecate, urinate, or spit on } \\
\text { green things (plants) or spit into water. }\end{array}$ & $\begin{array}{l}\text { Rivers and canals were clean, and germ } \\
\text { did not spread. }\end{array}$ \\
\hline Forbid to cut trees or destroy forests. & $\begin{array}{l}\text { Forbid monks to destroy trees having the } \\
\text { following appearances: } \\
\text { 1) Plants came from rootstocks, such as } \\
\text { Curcuma, Ginger, Sweet Flag, Galangal, Cyprus } \\
\text { Rotundus Linn, etc. } \\
\text { 2) Plants came from trunks, such as Sacred } \\
\text { Flag, Fiddle-leaf Fig, Long Pepper, etc. } \\
\text { 3) Plants came from buds, such as Sugarcane, } \\
\text { Bamboo, Cattail, etc. } \\
\text { 4) Plants came from treetops, such as Morning } \\
\text { Glory, Lemon Basil, Bai-ya-nang, etc. } \\
\text { 5. Plants came from seeds, such as Rice, Peas, } \\
\text { Sesame, etc. }\end{array}$ & $\begin{array}{l}\text { Rare seedlings did not become extinct. } \\
\text { The ecology had the balancing. The } \\
\text { environmental criminal problem was } \\
\text { decreased, especially the deforestation. }\end{array}$ \\
\hline Forbid to dig or order others to dig soil. & $\begin{array}{l}\text { because animals might be killed if tools used for } \\
\text { digging in soil caught animals living in those } \\
\text { areas. }\end{array}$ & \multirow{3}{*}{$\begin{array}{l}\text { Wildlife conservation did not become } \\
\text { extinct. The ecology had the balancing. } \\
\text { Several environmental criminal problems } \\
\text { were declined, for instance illegal wildlife } \\
\text { trading and smuggling, butchery, } \\
\text { polluting waste into river or air and } \\
\text { violating some significant environmental } \\
\text { laws and regulations. }\end{array}$} \\
\hline Forbid to kill animals. & $\begin{array}{l}\text { Killing animals was a sin if much attempt was } \\
\text { used. The much or longer time was used for } \\
\text { planning or preparing, the more there was a sin. }\end{array}$ & \\
\hline $\begin{array}{l}\text { Forbid to eat } 9 \text { kinds of meat which should } \\
\text { not be eaten. }\end{array}$ & $\begin{array}{c}9 \text { kinds of meat which should not be eaten were } \\
\text { meat of elephants, of horses, of dogs, of snakes, } \\
\text { of lions, of Bengal tiger, of leopards, of bears, } \\
\text { and of foxes. }\end{array}$ & \\
\hline Forbid to light fire for warming oneself. & $\begin{array}{l}\text { Lighting fire for warming oneself might spread } \\
\text { and destroy wild animals' habitation. }\end{array}$ & $\begin{array}{c}\text { There was not the dust which was } \\
\text { dangerous for the life like PM } 2.5 \\
\text { Creating more responsible man for } \\
\text { society. }\end{array}$ \\
\hline
\end{tabular}

can be applied in the modern society for being the ways to keep the environment sustainably. It can be concluded briefly as follows.

It showed that if we could take the discipline which Lord Buddha enacted and used them as the ways to take care of the environment. The sustainability would occur. From Table 2, it can be concluded that the Buddhist's code of monastic rules related to environment according to what the author studied includes 6 points as following:

1. Monks are not allowed to throw dirty things into rivers such as monks are prohibited to excrete their urine or feces or spilt their saliva into green objects (plants) or into water which can cause rivers and canals dirty and become the places that spread germs. This provision has an effect until today which can be applied to daily life, especially during the spread of Covid-19 that everyone needs to take special care of themselves and not to spread diseases to other people.
2. Monks are not allowed to chop down trees or deforest. Trees that cannot be cut down destroyed have the following characteristics: trees grow from rhizomes, i.e. turmeric, ginger, sweet flag, galangal, nut grass; trees grow from trunks, i.e. bodhi tree, banyan tree, long pepper; trees grow from buds, i.e. sugarcane, bamboo, reed grass; trees grow from treetops, i.e. morning glory, hairy basil, Ya-nang; trees grow from seeds, i.e. rice, bean, sesame, etc. By doing this, it helps conserve environment and protect rare plants from becoming extinct, bringing about balance of the ecosystem and reducing environmental crime related to deforestation.

3. The Buddhist's code of monastic rules prohibits monks from digging soil or causing it to be dug since there would be animals living inside the soil. Digging soil would kill animals living in those areas, contributing to destruction of the ecosystem. 
4. Monks are not allowed to kill animals. Killing animals is considered a sin since it requires a great attempt or takes much time for planning and preparation. In addition to refraining from committing a sin, today killing preserved species of animals or doing harm to animals is considered illegal. Therefore, refraining from killing animals is not only not to commit a sin but also produces good results, protecting rare species animals from becoming extinct, producing balance of the ecosystem and reducing environmental crime related to killing animals.

5. Monks are not allowed to eat 9 types of meat, i.e. elephant, horse, domestic dog, snake, lion, Bengal tiger, leopard, bear and fox since they are big and some are among the most ferocious animals and in order to kill them a great plan and effort are required. Consequently, it is considered a gravely sinful act. Nowadays, it is not suitable to kill those animals for food since some species of animals are going to be extinct. If killing those animals for food still gains popularity, it is not only committing a sin but also an illegal action and causes imbalance of the ecosystem.

6. Monks are not allowed to build a fire for warmth since the fire may burn living places of wild animals. As of today, it may produce bad effects on environment and harmful dust like PM 2.5 particles.

\section{CONCLUSION}

Given Buddhism's major role in Thailand's history, this paper explored how Buddhist principles and disciplinary rules can be applied to contemporary life to guide individuals, cities and the larger society toward environmental problem overview and environmental protection. Population growth, human activity and cultural shifts are relevant to the discussion. Moreover, temples such as Wat Pavaranivesh Vihara Rajavaravihara, Wat Nyanavesakavan and Wat Khao Banchop can serve as examples of humans living in a way that conserves nature.

Additionally, this paper focus on the Buddhism ways to maintain the environment by taking the discipline enactment to apply with the modern society to solve the environmental problems and lessen the environmental crime which usually occurred at present, such as the discipline of Buddhism teaching at every level, such as five-precepts, or the kindness discipline in the group of Four sublime states of mind. The sublime states of mind were Lord Buddha's discipline for everyone. However, they were only one part of discipline enactment in Tripitaka. To further the widespread knowledge regarding Buddhism laws and regulation and environmental problem, the evidencebase study on more disciplines in other enactments, such as Arrunyakasoot, Kalamasoot, or Ubosotsoot etc. should be implemented with the beneficial applying them into the modern society to solve the environmental problems and crime against environment occurring at present concretely.

\section{ACKNOWLEDGEMENTS}

None.

\section{DECLARATION OF INTEREST STATEMENT}

No potential competing interest was reported by the authors.

\section{REFERENCES}

Aroonwipada W. (2016). The participation of citizen in environmental crime prevention: A case study of Bangkok Metropolitan Area. Rangsit University [Online Publicized Master Thesis] Retrieved on May, 172021 from https://www.rsu.ac.th/ cja/IS/17-WEERASAK_AROONWIPADA-2559.pdf

Bhunyanuphab, S. (2011). The Tipitaka Version of the People. $18^{\text {th }}$ ed. Bangkok: Mahamakut Buddhist University.

Channarong, K. (1992). Teaching Handout on forest development laws. Nonthaburi: Agriculture and Cooperatives Promotion Program. Nonthaburi: Sukhothai Thammathirat Open University.

Chanocha, P. (2017). The role of Thai University in Thailand 4.0. Royal Thai Government: Bangkok. Retrieved April 12, 2021 from www.thaigov.go.th.

Chantavanich, S. (2012). Sociological Theories. 5th ed. Bangkok: Chulalongkorn University Press.

Chapilanan S. (1994). Crime: Current social problem should be solved. $1^{\text {st }}$ ed. Bangkok: Thai Wattana Printing Press.

Choeikiwong, U. (2012). Global Warming. Bangkok: Sangdao Printing Publication.

Chumsai Na Ayudhya, A.and Dhammasakiyo, A. (2015). Buddhism with Globalization. Nakhon Pathom: Mahamakut Buddhist University Press.

Dokbua, F. (1999). Buddhism with Thai People. Bangkok: Silapa Bannakarn.

Gottfredson, M. R., and Travis H. (1990). A general theory of crime. Stanford, Calif: Stanford University Press.

Green Peace Group. (2017). The Pollution particulate matter 2.5 micrometers or less PM2.5 of Thailand January-June 2017. Retrieved April 10, 2021 from (https://www.greenpeace.or.th/ s/right-toclean- air/PM2.5-in-Thailand_Jan-Jun2017.pdf)

Institute for Population and Social Research (2018). Mahido Population Gazette. Nakhon Pathom: Mahidol University Retrieved March, 2, 2021 from http://ipsr.mahidol.ac.th. 
Jitsawang N. (2016). Green Criminology. Retrieved February 18, 2021 from (http://www.nathee-chitsawang.com).

Ketsil, T. (2020). Environmental Management According to Buddhist. Bangkok: Danex Inter Corporation Co., Ltd.

Learning Center for Earth Science and Astronomy: LESA (2021) World population increase. Retrieved March, 172021 from http://www.lesa.biz/earth/global-change/world-population.

Lydia V., William E. T.Jr., Leo B. and Jerrol M. S. (1994). Criminology and Justice. New York: McGraw-Hill.

Mahamakut Buddhist University (2014). Tripitaka and commentary, volume set. $8^{\text {th }}$ Edition. Nakhon Pathom: Mahamakut Buddhist University Printing.

Moral Promotion Center of Mahidol University. (2010). Summary of Research Reports Toward Promoting and Development of Moral in Media in Thai Society. Bangkok: Printing at G-Art Co., Ltd.

Nawikkamun, A. (2006). Temple in Bangkok - Thonburi. 3rd ed. Bangkok: Sangdat Plendek.

Nyanaponika T. (2013). The Four Sublime States: Contemplations on Love, Compassion, Sympathetic Joy and Equanimity. BCBS Ed. Retrieved April, 10, 2021 from http://www.accesstoinsight.org/lib/authors/nyanaponika/whee I006.html.

Office of Natural Resources and Environment Policy and Planning: ONEP. (2019). The situation of forest resources in Thailand. Bangkok. Retrieved April, 20 2019. from http://www.onep.go.th.

Received on 18-05-2021

Accepted on 12-07-2021

Published on 19-07-2021

https://doi.org/10.6000/1929-4409.2021.10.143

(c) 2021 Tititampruk and Ketsil; Licensee Lifescience Global.

This is an open access article licensed under the terms of the Creative Commons Attribution Non-Commercial License (http://creativecommons.org/licenses/by-nc/3.0/) which permits unrestricted, non-commercial use, distribution and reproduction in any medium, provided the work is properly cited.
Osathanugrah, A. (2006). The Two Raja, Vol. 7. Bangkok: The Ruam Doiy Choiy Gan Publishing House.

Phrakhru Atthajariyanuwat, S. S. (2017). Buddhism Criminology: Buddhist approached on crime. RTNA Journal of Social Sciences, Humanities and Education. 4(1), 28-39.

Royal Forest Department (2014). Information regarding Thai Forest. Bangkok. Retrieved March, 142021 from http://forestinfo.forest.go.th.

Royal Forest Department (2018). Areas of Community Forest. Bangkok. Retrieved March, 142021 from http://forestinfo.forest.go.th.

Somdet Phra Buddhakosajarn, P. (2017). Buddha in the World of Justice. 8th ed. Bangkok: Pet \& Home Publishing Co., Ltd.

Siripatanadilox, S. (1992). Training Handout on the forest development in the high area, Forestry Research Center of Faculty of Forestry, Bangkok: Kasetsart University.

Thammachote. (2016). Online Tripitaka. Retrieved May, 172021 from https://tripitaka-online.blogspot.com/2016/06/sl003.html Reserving National Environmental Quality, Vol. 135, Part 27. Bangkok: Cabinet and Royal Gazette Publishing Office.

Theerapong B. (2019) The Crisis Lessons from PM 2.5 Air Pollution, EAU HERITAGE JOURNAL Science and Technology, 13(3) 44-58. https://he01.tci-thaijo.org/index.php/EAUHJSci/article/ view/231508/157720

Uttamapunyo, P.T. (2018). Bhikkhu Patimokkha Translation. $3^{\text {rd }}$ ed. Bangkok: Prayoon Sarasin.
The Government Gazette. (2018). The Act of Promoting and 